\title{
Correction: Cerebral venous sinus thrombosis during superselective intra-arterial infusion of cisplatin and concomitant radiotherapy for maxillary squamous cell carcinoma
}

Okamura S, Saito Y, Mori H, Yamasoba T. Cerebral venous sinus thrombosis during superselective intra-arterial infusion of cisplatin and concomitant radiotherapy for maxillary squamous cell carcinoma. BMJ Case Rep. Published Online First: 12 May 2017. doi:10.1136/ bcr-2017-220591

The line '(1) the indwelling catheter in;' should read:

(1) the indwelling catheter in the common carotid artery decreased brain venous flow;

(C) BMJ Publishing Group Ltd (unless otherwise stated in the text of the article) 2017. All rights reserved. No commercial use is permitted unless otherwise expressly granted.

BMJ Case Rep 2017. doi:10.1136/bcr-2017-220591corr1

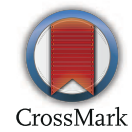

Copyright 2017 BMJ Publishing Group. All rights reserved. For permission to reuse any of this content visit http://group.bmj.com/group/rights-licensing/permissions.

BMJ Case Report Fellows may re-use this article for personal use and teaching without any further permission.

Become a Fellow of BMJ Case Reports today and you can:

- Submit as many cases as you like

- Enjoy fast sympathetic peer review and rapid publication of accepted articles

- Access all the published articles

Re-use any of the published material for personal use and teaching without further permission

For information on Institutional Fellowships contact consortiasales@bmjgroup.com

Visit casereports.bmj.com for more articles like this and to become a Fellow 